\title{
Barriers that Prevent Micro-Business Owners from Outsourcing Non- Essential Services
}

\author{
Carla Kingston-Floyd ${ }^{1}$, Rami Alasadi ${ }^{2}$ \\ ${ }^{1}$ SEA Program Coordinator, St. Lawrence College (Cornwall Campus) Canada \\ ckingston@sl.on.ca \\ ${ }^{2}$ Department: MBA, Cape Breton University, Shannon School of Business, Canada \\ ramiasadi@hotmail.com
}

\begin{abstract}
This paper explores the possible barriers that prevent micro-business owners (with a specific focus on the participants in the Self Employment Assistance Program in Cornwall Ontario Canada from outsourcing non-essential services. The paper will include both primary and secondary research to ascertain those barriers. The Findings show that although the respondents of the survey are aware of the benefits of outsourcing their non-essential business activities, they are still reluctant to outsource activities beyond the year-end tax preparation. It seems apparent that the respondents see outsourcing as an option for bigger businesses as $79.2 \%$ of them said they would outsource when their business grew.
\end{abstract}

\section{Indexing terms/Keywords}

Self-employment, Micro-business, Outsourcing

\section{Academic Discipline And Sub-Disciplines}

Business and Management

\section{SUBJECT CLASSIFICATION}

Small Business

\section{TYPE (METHOD/APPROACH)}

Survey

\section{Council for Innovative Research}

Peer Review Research Publishing System

Journal: International Journal of Management \& Information Technology

Vol. 9, No. 1

editor@cirworld.com

www.cirworld.com, member.cirworld.com 


\section{INTRODUCTION}

The emergence of subcontracting or outsourcing of non-essential services has been a strategy of many successful organizations for numerous years. Although the benefits of the outsourcing strategy are well known in manufacturing and large organizations, there has been little information gathered on the benefits of outsourcing non-essential services to micro-enterprises. There are over one million small businesses in Canada that have employees that work for them, and this total doesn't include the 2.67 million self-employed entrepreneurs that were in existed in 2011. Ninety-Eight percent of the over one million small businesses in Canada have less than one hundred employees (Industry Canada, 2012).

These small and micro-businesses are vitally important to the economy as they provide forty-eight percent of the jobs that Canadians hold (Industry Canada, 2012). Most of these small and micro-business are in the service sector (79\%) with the remaining $21 \%$ being in the business of offering goods to consumers (Industry Canada, 2012). The current statistics show that $85 \%$ of these businesses will survive the first year of business, but only $51 \%$ of them will make it to the fifth year successfully (Industry Canada, 2012).

Services that tend to be outsourced include: bookkeeping, financial reporting, year-end-tax preparation, marketing, advertising, information technology, and some human resource activities. Using outsourcing of non-essential services as a strategy allows the business owners and employees to focus on the business's core activities. As some companies grow in size they move back away from outsourcing and hire inside staff to perform the above duties, this is commonly referred to as "insourcing".

Micro-entrepreneurs that have participated in the Self Employment Assistance Program in South-Eastern Ontario tend to outsource very few non-essential services with the most common ones being year-end tax preparation and information technology for computer breakdowns or loss of vital information on their systems. It seems like commonsense that performing all of the non-essential services would away valuable time from the micro-entrepreneurs that could be better spent focusing on the core business and revenue generating activities. It also seems that the microentrepreneurs may miss out on some competitive advantages of having experts completing the non-essential services for them. For example, it may advantageous to outsource promotional activities to the sector experts who know the most effective means of reaching potential target customers versus employing a trial and error strategy this could be both expensive and ineffective.

The research question that we are addressing in this paper is: What barriers prevent micro-entrepreneurs from outsourcing non-essential services?

\section{SIGNIFICANCE OF THE STUDY}

The paper will shed a light on the barriers that micro-entrepreneurs face with respect to outsourcing non-essential services. The findings of this paper can be used by different bodies that are involved in Self Employment programs where they can employ strategies to help remove some of the barriers. Additionally, the paper can help the microentrepreneurs to focus their energy, efforts, and time on growth and revenue generation for their business thus allowing them a better chance of long term business success.

\section{SUPPORTING LITERATURE REVIEW}

Should the organization do all of the activities of their business in-house or hire the products or services out? It would seem like a straight forward question that would depend on the attitude of the owner and yet, making the right decision about outsourcing is a lot more daunting than one may think. In fact, a review of the literature may have business owners change their preconceived notions about outsourcing or reinforce that their previous perception is the right decision for their organization.

In a paper written by Richard Bartem and Sherry Manning, the authors said that in order to decide whether or not a company should consider outsourcing they need to consider the following:

"Is the function well managed at the present time? Do we have good people? Are our people learning to continually enhance the way this service is performed? Are costs accounted for and under control? Is the community happy with the service? Are we meeting our own standards of quality? Are we keeping up with technology? Are we able to invest the capital needed to stay up to date?" (Bartem \& Manning, 2001).

In order to get true answers to the above questions, the owner is required to take a "dispassionate" look at the needs of the organization (Bartem et al., 2001).

\section{LITERATURE IN SUPPORT OF OUTSOURCING}

There is a lot of literature that supports outsourcing (also known as subcontracting) as a viable option that allows business owners to focus on the core services of their business by having non-essential tasks handled by other outside companies. The most common activity that is currently outsourced is in the area of Information Technology (IT) and the reasons for outsourcing IT support are: 52\% cost effectiveness, $26 \%$ access to better resources, $14 \%$ historical relationship, and $9 \%$ other reasons (Krell, 2011). Technology developments have given small businesses 
access to sophisticated information systems at more affordable prices and cloud computing has enabled many more small businesses to leverage third-party expertise (Krell, 2011).

Outsourcing Gives Access to Expertise. Outsourcing is a great option for businesses that don't have or can't hire the skills they need and gives the business access to expertise that they may not have previously had at their disposal (Bartem et al.,2001; Smalley, 2004). Outsourcing means giving responsibility to experts in particular fields which provides access to a higher quality of service thereby giving the organization a competitive advantage (Reid, 2004/05). Outsourcers can bring hard-to-find expertise and fresh ways of thinking to some of the most pressing business challenges (Preston, 2012). David Ehrenberg practically insists that new start-up companies should outsource their human resource functions which would give them a competitive advantage that would outweigh the cost of this function (Ehrenberg, 2012). David continues to point out that the benefits of having the right well-trained staff in place that are in compliance produces greater benefits in the long-term success of the company (Ehrenberg, 2012). Cameron Herold states that "Entrepreneurs hire accountants; they don't do accounting" (Ted Talks, 2010)

In a survey completed by Pricewaterhouse Coopers in 2007, seventy percent of the 292 respondents named access to talent as the most important reason to outsource (Price Waterhouse Coopers, 2007). The December 2010 Journal of Management Studies confirms that having access to talent and farming out activities to companies that can perform that duty better than you is becoming a more popular reason to outsource than cost savings alone (Mudambi, Tallman, 2010). Besides getting access to talent and expertise, another spin on the decision to outsource is that the organization also gains access to new technologies being used by the experts in their fields that they may not have had access to by completing the task in-house (Juras, 2007). Companies currently outsourcing IT cite having access to the latest technology without having to invest in new systems as a main benefit along with relieving the pressure of keeping up to date with industry trends and IT training (Reid, 2004/05). The learning curve must also be taken into consideration especially if the organization has a high staff turnover where constant retraining can reduce efficiencies and expertise (Baxendale, 2004).

In a study done by Achieve Global, over 1,750 senior-level executives stated the key reason for outsourcing was "to use the expertise of specialists" over their prior thoughts that outsourcing was a way to gain a competitive advantage through cost savings (Achieveglobal, 1998).

Small business owners can also benefit from outsourcing by turning over parts of their business operations to outside experts (Krotz, 2011). Getting access to specialist in areas such as graphic design, sales and marketing can give small businesses the same competitive edge that the practice of outsourcing imparts to larger organizations (Krotz, 2011). In the article written by Barczyk, Husain, and Green, they concur that very small enterprises should outsource when the owner is not skilled in handling the activity (Barczyk, Husain, Green, 2007). The benefit of outsourcing regarding the access to skills

can be best summed up by Kremic who states "The partnerships that result from outsourcing may enable an organization to be a world-class performer for a whole suite of products and services where it could only be an average performer by itself" (Kremic, et al 2006)

Outsourcing Gives a Potential for Cost Savings. The literature review on the benefits of cost savings was the primary reason that business owners outsourced in the early days. Outsourcing allows companies to cut costs (Baxendale, 2004; Bulter, 2000; Domberger and Fernandez,1999; Hammonds, 1994; Hui-Ming, et al, 2010; Krell, 2011; Kumar \& Eickhoff. 2005; Liu, et al 2008; Mourdoukoukoutas, 2011; Mullerpattan, 2009; Prahalad, Hamel, 1990; Reid, 2004/05; Vitasket, 2010).

Outsourcing allows businesses to save up to $40 \%$ in costs by hiring subcontractors on an as needed basis instead of maintaining full time staff members costing them both in salary and benefit packages (Hammonds, 1994). Outsourcing gives the business access to expertise that they may not have previously had at their disposal and the benefits of economies of scale buying with that supplier (Bulter, 2000). Early outsourcing has helped companies see balance sheet improvements, access lower-cost labour and often improve productivity (Vitasket, 2010).

Suppliers of the products or services that are outsourced are able to operate with a reduced level of overhead due to their focus on the operation and efficiencies that they gain because it is their area of expertise (Kumar \& Eickhoff. 2005). These cost advantages also come to the businesses that decide to outsource because there is less of a capital demand for the needed assets, infrastructure, and staff to make the product or delivery of the service (Kumar \& Eickhoff. 2005). Outsourcing reduces the demand for capital and labour resources (Hui-Ming, W. et al. 2010).

A survey of 7,500 public organizations in Australia who outsourced their cleaning services resulted in a savings of 46 percent over the cost of performing the cleaning with in-house staff members (Domberger \& Fernandex, 1999). This is achieved through efficiencies gained in the repetition of the same duties (Kumar \& Eickhoff. 2005). The reading of the literature on cost savings appears to be broken into two phases; the early phase of outsourcing saw cost savings as the primary reason to outsource whereas the second phase of outsourcing sees the benefits of outsourcing as partnerships with complementary areas of expertise.

Outsourcing Allows the Organization to be Able to Focus on the Core Activities of the Business. Outsourcing has been cited as allowing the organization to become more flexible, entrepreneurial in its pursuits of new products and/or services, gain efficiencies by focusing on their strengths, and making them more responsive to their target customer's needs (Bartem et al., 2001). This fact is also supported in the work of Kumar and Eickhoff that states outsourcing allows the business to focus on a handful of core competencies, and then hire out the remaining business functions to 
subcontractors. A core competency should be difficult for a competitor to duplicate which gives the organization a competitive advantage over its competitors (Prahalad \& Hamel, 1990). Although in their opinion, they believe that too many companies have unknowingly surrendered some of their core competencies when they cut internal investment in what they mistakenly thought were just "cost centres" in favour of outside suppliers which takes away some of their competitive advantage (Prahalad, \& Hamel, 1990). Kumar and Eickhoff also state that when a company is able to focus on the business core functions, it gives the business a competitive advantage by being able to differentiate itself from its competitors (Kumar \& Eickhoff. 2005). This competitive advantage can also be given to small businesses by outsourcing non-core activities which would allow the owners to focus on critical needs and growth of the business (Krotz, 2011). In the article "Bigger doesn't Mean Better" the author states that small businesses can also save time, money and effort by concentrating on and developing areas of strength, thus making the business more competitive (Reid, 2004/05).

Outsourcing Gives the Organization Greater Flexibility. When a company reduces its debt and risk that is associated with in-sourcing it gains flexibility (Kumar \& Eickhoff. 2005). Flexibility is an important driver in today's competitive environment with companies needing to respond quickly to satisfy their customers (Wee, H. et al. 2010). A competitive enterprise can satisfy their customers by improving their service speed, flexibility, and response expertise within a changing environment and by creating suitable outsourcing strategies (Hui-Ming, et al 2010). In the long run, a company's competitive advantage comes from its ability to develop its core competencies that lead to the development of unanticipated products and/or services being offered before their competitors. The authors allude to the fact that companies need to be innovative in developing products and/or services that customers don't know they need or want yet (Hui-Ming, et al 2010).

Reasons that Speak Specifically to Why Small Businesses Should Outsource. Small- businesses are now outsourcing a range of services from Human Resource functions to finance and accounting to customer services which includes the use of outsourced call centers (Krotz, 2011). But, the author cautions that the outsourcing process requires some time and financial investment to "find the right vendor, build a working relationship, and allow your employees to adjust" (Krotz, 2011). It is a good idea to test the supplier's performance and see how the relationship works out before signing a long-term contract (Krotz, 2011). The author recommends starting small or with "one-off projects" and build from there as their confidence and comfort levels increase (Krotz, 2011). Getting the help of specialists and experts in their fields such as graphic design, sales \& marketing, and bookkeeping can save your organization significantly by not wasting your time or money trying to reach the wrong customers or making costly errors in your financial management (Krotz, 2011).

"If your business is one with no or very few employees you may find yourself over-stretched for time, and in need of outsourcing" (Mullerpattan, 2009). Driven by the economy and the need to watch expenses, some businesses outsource so they can hold off on hiring in-house employees (Mullerpattan, 2009). Technology such as using Skype conversations and social networks help those who have never met develop trusting relationships and are becoming a means for small business owners to reach out and establish relationships with their outsourcing partners (Mullerpattan, 2009). In outsourcing the mantra is "Communication, communication, communication" and technology is assisting with that need (Mullerpattan, 2009).

Finance is only one dimension for small businesses to consider when looking at the option of outsourcing. They also need to consider other factors such as flexibility, trust, quality, dependability, timeliness, and reliability when choosing outsourcing partners (Baxendale, 2004).

\section{CAUTIONS AND/OR CONCERNS WITH OUTSOURCING}

Unrealized cost savings. Some literature supports the idea of outsourcing for the cost savings, but other literature cautions that there are no guarantees that those savings will actually be realized (Domberger \& Fernandez, 1999). In fact, some literature actually shows that cost savings have been overstated or sometimes higher as a result of outsourcing (Domberger \& Fernandez, 1999). In a survey completed by Domberger and Fernandez, they found that outsourcing IT actually resulted in an average increase in costs of nine percent (Domberger \& Fernandez, 1999). Outsourcing can be easily replicated by the competition so the cost savings can be short lived (Mourdoukoutas, 2011). It doesn't give the company a sustainable competitive advantage; for example if call centres reduce their cost for Bell they can also pass those same cost savings to Telus, Rogers and other cell phone providers thus making the advantage of outsourcing a short term gain (Mourdoukoutas, 2011). Outsourcing also makes it easier for new competitors to join the market as they can purchase the product and services from established outsourcing companies instead of trying to develop them in-house (Mourdoukoutas, 2011).

Authors of the Outsourcing in Higher Education: A Business Officer and a Business Partner Discuss a Controversial Management Strategy acknowledge that on occasion, outsourcing will fail. The main cause of the failure in outsourcing is a direct result of poor communication between the two organizations (Bratem et al., 2001).

Outsourcing requires trust and optimal communication. Subcontracting does have one major drawback in that it does require trust because the owner of the business must give up some of their control over the quality and timeliness of the work that is being subcontracted (Bulter, 2000; Smalley, 2004; Kremic, et al 2006). If the outsourcing happens overseas the organization faces more risk with the fluctuating currency values, risk of changes in political leaders which may make the local government harder to do business with (Kumar \& Eickhoff. 2005). 
The risk of intellectual property can affect both the outsourcing firm and its vendor negatively because sharing the information that is needed to outsource the activity successfully might require sharing trade secrets which makes both parties vulnerable (Kumar \& Eickhoff. 2005). Even with the best contracts in place, agreements can still be broken without the other parties' knowledge which can lead to one party reproducing the organization's product or sharing their competitive advantage with another business (Kumar \& Eickhoff. 2005).

Outsourcing requires communication and coordination to manage processes across firm boundaries (Whitaker, et al 2011). Differences and distances between countries pose obstacles to the flow of information and transfer of knowledge between partner firms (Whitaker, et al 2011). Some of these differences are not yet fully understood in offshore outsourcing and present unique financial, legal, and managerial risk compared with onshore outsourcing (Whitaker, et al 2011). There is also a need for systems to be able to communicate with each other which may increase costs and skill level knowledge (Whitaker, et al 2011).

Outsourcing can lead to a shortage of internal expertise. The new General Motors CIO, Randy Mott, made national headlines when he stated that he plans to reverse the automaker's historical reliance on IT outsourcing, in hopes of executing projects faster and cultivating auto technology expertise internally (Preston, 2012). If an organization doesn't develop the talent in-house they become too dependent on the supplier (Kremic, et al 2006). This lack of talent also leads to lost corporate knowledge which may reduce future growth and competitiveness (Kremic, et al 2006). Outsourcing can provide a shortcut to a competitive product, but it usually doesn't contribute to building skills that are needed to sustain product leadership (Prahalad, \& Hamel, 1990). Outsourcing can also make managers lazy and become complacent relying on cost savings instead of monitoring competitors, watching for future market opportunities and focusing on new product development (Mourdoukoutas. 2011).

Risk of the outsourcing company not delivering. There is another risk of outsourcing if the supplier of the product or services is unable to deliver due to bankruptcy, lack of funds, or labour problems (Kumar \& Eickhoff. 2005). Political unrest may also put the supplier at risk of sabotage or local attacks (Kumar \& Eickhoff. 2005). Manufacturing companies need to consider the impact on financials and customer retention when outsourcing companies cannot meet deadlines and commitments (Liu, \& Tu, 2008).

The Impact of Outsourcing on the Morale of In-House Staff. Another concern of outsourcing it that it may reduce the efficiency of the current in-house staff members as they question their job security and loyalty of their employer (Kumar \& Eickhoff. 2005; Kremic., T et al 2006). Outsourcing may also make it harder for the leaders of the organization to get employee buy-in with employees losing faith in management (Kumar \& Eickhoff. 2005).

In the Winning the Outsourcing Game book, editor Janet Bulter, alludes to concerns of outsourcing on the morale of remaining employees worrying that their jobs may also become the victim of being outsourced (Bulter, 2000). Other works state that outsourcing can lead to a loss of loyalty and employees worry about losing their jobs (Mourdoukoutas, 2011). Outsourcing has had an impact on manufacturing jobs with less than $11 \%$ of Americans being employed in this sector and over 3.3 million service jobs are predicted to be moved to lower cost countries by 2015 which will have employees fearful of losing their jobs (Kumar \& Eickhoff. 2005).

Outsourcing can lead to a Disconnect. A loss of connection with customers and communities may result due to outsourcing (Mourdoukoutas, 2011). For example "if I hire Sears or Home Depot to make certain improvements in my home because they have a reputation for reliable services, I would feel betrayed if I get services from strangers hired by the said companies, especially if they perform a sloppy job" (Mourdoukoutas, 2011). Any breakdown in service quality can negatively impact the client firm's ability to maintain and expand its customer base (Whitaker, et al 2011) There is a loss of the connection with the community that the company doesn't do business with and the customers in that community may start to boycott that company's products or services. (Mourdoukoutas, 2011).

When contracts and relationships are properly thought out, vetted, and managed, they can deliver strong results, especially when they're tied to strategic business outcomes and not just brute cost savings (Preston, 2012). Joint planning, co-ordination and process integration between the suppliers and their customers can assist management in making the right outsourcing decisions (Hui-Ming, et al. 2010). This is reinforced in the work of Rai, Keil, Hornyak and Willenweber when they say you need to have good governance in the relationship and contracts with your outsourcing partners (Rai, et al. 2012).

Re-evaluation is an important component of outsourcing and the performance of the supplier must be regularly measured against the outsourcing agreement (Kumar \& Eickhoff, 2005). This point is reemphasized in the Journal of Management Information System where the authors state the importance of having both relational and contractual governance. The concept is to stay involved with the vendors and use collaboration practices to help reduce the risks associated with outsourcing (Rai, et al 2012). This fact is supported by Hui-Ming Wee with suggestions of collaborating with suppliers in order to reduce risk and uncertainty that comes with outsourcing (Wee, H. et al. 2010). Like alliances, outsourcing experience contributes to development of routines that enable firms to collaborate with a range of partners. Experienced firms can more effectively identify and select trustworthy suppliers, negotiate and organize relations, monitor and enforce terms, and anticipate and respond to contingencies based on learning from prior sourcing engagements. Firms with greater sourcing experience are more likely to outsource because they have learned the administrative routines that enhance their abilities to engage in successful sourcing partnerships (Whitaker, et al 2011). 


\section{RESEARCH METHODOLOGY}

This paper uses quantitative data collection. A survey was decided to be the most effective means of gathering the primary data required for this paper. The survey was circulated to 200 participants with $34 \%$ of them completing the questionnaire. The survey consisted of nine questions which allowed the data to be standardized to ensure ease of comparison. Most findings were represented as a percentage of respondents to a particular question with the context of the survey. To ensure anonymity, "Survey Monkey" was used as the tool to collect the responses from the participants. It was thought that the use of a third party collection method would make the respondents more comfortable with their participation in the survey, along with the added freedom of being completely honest in their responses, knowing that a link could not be made between respondents and responses.

The sample of the study was the participants in the Self Employment Assistance Program in Cornwall Ontario Canada. The focus of the survey was to see if any past and/or current Self Employment Assistance participants are outsourcing any of their non-essential services. The research analysis will look for commonalities in which services are outsourced the most versus which areas the business owners chose to complete in-house. There will also be close attention paid to the reasons given for not using outsourcing as a business strategy to see if there are majorities in certain choices that may become a future strategy of the Self Employment Assistance Program.

\section{FINDINGS}

The survey was sent to 200 people through email with a link to the Survey Monkey site. A total of 68 responses came back which is a $34 \%$ participation rate in the survey. The highest participation in the survey came from the professional advising group (17.3\%) followed by the construction/renovations/handi-man group (15.4\%) which makes sense as those two sectors represent the highest number of participants in our overall program. The retail sector had a $9.6 \%$ representation, landscaping and manufacturing represented $5.8 \%$ of the overall responses, and both the food sector and automotive sector had $3.8 \%$ representation.

The survey results showed that only $52.8 \%$ of the respondents outsourced any of their non-essential services. Over half of the respondents (53.5\%) stated that a benefit of outsourcing was that it would allow the business owner to focus more on the core business activities, yet, a contradicting fact showed that $47.2 \%$ of respondents spend $11-25$ $\%$ of their time doing non- essential services and $15.1 \%$ of respondents actually spend more than $25 \%$ of their time on activities that do not generate any income.

The activity that was identified as being outsourced the most is the year-end taxes $(82.1 \%)$ followed by $21.4 \%$ of respondents outsourcing their businesses' marketing and design needs.

The largest reason for not outsourcing non-revenue generating activities by the respondents was the fact that $47.8 \%$ thought that they currently had the skills to be able to complete the tasks themselves. This result will need to be investigated further as it may be a direct result of the training given in the Self Employment Assistance Program. The next reason for not outsourcing was the thought that it was too expensive to outsource followed by the third reason which was a concern for the quality of work that would be done if the task was outsourced.

The biggest surprise in the results of the survey is the fact that $79.2 \%$ of the respondents said that they will outsource non-essential services once their business grows. This statement gives the impression that the respondents see outsourcing as a practice for big business.

\section{CONCLUSION}

Overall, it appears that although the respondents of the survey are aware of the benefits of outsourcing their nonessential business activities, they are still reluctant to outsource activities beyond the year-end tax preparation. It seems apparent that the respondents see outsourcing as an option for bigger businesses as $79.2 \%$ of them said they would outsource when their business grew.

Another area of interest in the survey results is the fact that $47.8 \%$ of the respondents feel that they have the necessary skills to complete the non-essential tasks on their own. The Self Employment Assistance Program provides workshops in the areas of: market research, recordkeeping, advertising and branding, sales, and HST, but with the focus on making the participants better equipped to talk with professionals in those fields. This is an area that will need further exploration in the Self Employment Assistance Program as we don't want the participants to feel that with 18 hours of instruction on advertising and branding that they have the skills to develop their business image and reach potential customers. This could actually be a negative result of the workshop if a person feels that they are equipped to choose their advertising venues only to waste precious resources on choosing the wrong means of reaching their customers. It would be advised to do the survey with microbusinesses that are not part of the Self Employment Assistance Program to see if those results are duplicated or vastly different.

Future areas of study should also be done with microbusinesses to see if there is a common belief that outsourcing is a luxury for bigger business only. If that is a common theme in the business community, further research should be done to ascertain why that mindset exists. Microbusinesses stand to benefit greatly from the expertise that comes along outsourcing. Outsourcing should in fact make their business more successful by giving them expertise, access to economies of scale, and the extra time for them to devote to their business core activities which generate income.

\section{REFERENCES}


[1] Barczyk,C., Husain, J. Green, S. 2007. Expertise of Owners, Investment of Time, and Human Resource Outsourcing in Very Small Businesses. Journal of Business 6 (1) pp. 39-50.

[2] Bartem, R., Manning, S. 2001, January. Outsourcing in Higher Education: A Business Officer and a Business Partner Discuss a Controversial Management Strategy pp. 42-47.

[3] Baxendale, S.J. 2004, January/February. Outsourcing Opportunities for small businesses: a quantitative analysis. Business Horizons, 47 (1)

[4] Besser, T. \& Miller, N. 2010. The Significance of Customer Base in the New Economy: Satisfaction of Success among Small Suppliers and Small Nonsuppliers. Journal of Small Business Management, 8 (1) pp. $1-15$.

[5] Bulter, J. 2000. Winning the Outsourcing Game: making the best deals and making them work.

[6] Dryden, R. \& Stanford, J. 2012, March. The Unintended Consequences of Outsourcing Cleaning Work.

[7] Ehrenberg, D. 2012, October 19. The 3 Jobs Your Startup Should Outsource.

[8] Hammonds, K. 1994, October 16. The New World of Work. Online Business Week Magazine.

[9] Herold, C., 2010, July 28. Let's Raise Kids to be Entrepreneurs. Ted Talks

[10] Huber, N. (n.d.) Win support from staff for outsourcing contracts.

[11] Industry Canada Small Business Branch Key Small Business Statistics. (2012, July).

[12] Juras, P. 2007. A Risk-Based Approach to Identifying the Total Cost of Outsourcing. Management Accounting Quarterly 9 (1) pp 43-50.

[13] Kotter, J. 2001. What Leaders Really Do? Harvard Business Review 79 (11) pp. 85-96.

[14] Krell, E. 2011. The State of Small Business. Baylor Business Review. 30 (1)

[15] Krotz, J. 2011. Tips for outsourcing your small-business needs. Microsoft Business.

[16] Kumar, S., Eickhoff, J. (2005). Outsourcing: When and How should it be done?

[17] Leach, G. 2004. The Economy. Director 57 (9) p.30.

[18] Liu, X. \& Tu, Y.L. 2008. Capacitated production planning with outsourcing in an OKP company. International Journal of Production Research 46 (20) DOI: 10.1080/00207540701348779.

[19] Miller, S. 2007. Collaboration Is Key To Effective Outsourcing. HR Magazine Volume 57.

[20] Mourdoukoutas, P., 2011, December 9. The Unintended Consequences of Outsourcing. Forbes

[21] Mudambi, S.M., Tallman, S. 2010. Make, Buy or Ally? Theorectical Perspectives on Knowledge Process Outsourcing through Alliances. Journal of Management Studies 47.Doi:10.1111/j.14676486.2010.00944.x

[22] Mullerpattan, A. 2009. Top 10 Outsourcing Trends by Small Businesses. Outsourcing comes of age: The rise of collaborative partnering. Global Outsourcing PriceWaterHouseCoopers.

[23] Peters, T., 2000. What Will We Do For Work. Time Europe 155 (21).

[24] Prahalad, C.K., Hamel, G. 1990, May-June. The Core Competence of the Corporation. Harvard Business Review.

[25] Publishing and Depository Services Public Works and Government Services Canada. (July 2012). Industry Canada Small Business Branch; Key Small Business Statistics.

[26] Quinn. J, Hilmer, F. 1995. Make Versus Buy. The McKinsey Quarterly.

[27] Rai, A., Keil, M., Hornyak, R., and Wullenweber, K. 2012. Hybrid Relational-Contractual Governance for Business Process Outsourcing. Journal of Management Information Systems. DOI:10.2753/MIS07421222290208.

[28] Reid, A. 2004/05 December/January. Bigger doesn't mean better: offshoring for SMEs. Engineering Management.

[29] Schofield, S. 2008 October. DOD Outsourcing: Are Cost Savings Estimates Overstated? Contract Management 48 (10) pp. 42-51.

[30] Smalley, K. 2004. Benefits of Outsourcing for Your Business. Strategic Resourcing Of Training \& Development A Key To Competitive Advantage. Achieve global.

[31] Wee, H., Peng, S., Wee,P. 2010. Modeling of outsourcing decisions in global supply chains. An empirical study on supplier management performance with different outsourcing strategies. International Journal of Production Research Vol. 48 (7). DOI: 10.1080/00207540802644852 


\section{ISSN 2278-5612}

[32] Whitaker, J., Mithas, S., Krishnan, M.S. 2010-2011. Organizational Learning and Capabilities for Onshore and Offshore Business Process Outsourcing. Journal of Management Information System. Doi:10.2753/MIS0742-1222270302 